\title{
Article
}

\section{D Physical Modeling of an Artificial Beach Nourishment: Laboratory Procedures and Nourishment Performance}

\author{
André Guimarães ${ }^{1, *(1)}$, Carlos Coelho ${ }^{1}\left(\mathbb{D}\right.$, Fernando Veloso-Gomes ${ }^{2}$ and Paulo A. Silva ${ }^{3} \mathbb{C}$ \\ 1 RISCO \& Civil Engineering Department, Campus Universitário de Santiago, University of Aveiro, \\ 3810-193 Aveiro, Portugal; ccoelho@ua.pt \\ 2 Civil Engineering Department, Faculty of Engineering, University of Porto, 4200-465 Porto, Portugal; \\ vgomes@fe.up.pt \\ 3 CESAM \& Physics Department, Campus Universitário de Santiago, University of Aveiro, \\ 3810-193 Aveiro, Portugal; psilva@ua.pt \\ * Correspondence: asaguimaraes@ua.pt
}

Citation: Guimarães, A.; Coelho, C.; Veloso-Gomes, F.; Silva, P.A. 3D Physical Modeling of an Artificial Beach Nourishment: Laboratory Procedures and Nourishment Performance. J. Mar. Sci. Eng. 2021, 9, 613. https://doi.org/10.3390/ jmse9060613

Academic Editor: Rodger Tomlinson

Received: 6 May 2021

Accepted: 29 May 2021

Published: 3 June 2021

Publisher's Note: MDPI stays neutral with regard to jurisdictional claims in published maps and institutional affiliations.

Copyright: (c) 2021 by the authors. Licensee MDPI, Basel, Switzerland. This article is an open access article distributed under the terms and conditions of the Creative Commons Attribution (CC BY) license (https:// creativecommons.org/licenses/by/ $4.0 /)$.

\begin{abstract}
Beach nourishment represents a type of coastal defense intervention, keeping the beach as a natural coastal defense system. Altering the cross-shore profile geometry, due to the introduction of new sediments, induces a non-equilibrium situation regarding the local wave dynamics. This work aims to increase our knowledge concerning 3D movable bed physical modeling and beach nourishment impacts on the hydrodynamics, sediment transport, and morphodynamics. A set of experiments with an artificial beach nourishment movable bed model was prepared. Hydrodynamic, sediment transport, and morphological variations and impacts due to the presence of the nourishment were monitored with specific equipment. Special attention was given to the number and positioning of the monitoring equipment and the inherent constraints of 3D movable beds laboratory tests. The nourishment induced changes in the beach dynamics, leading to an increase in the flow velocities range and suspended sediment concentration, and effectively increasing the emerged beach width. Predicting and anticipating the morphological evolution of the modeled beach has a major impact on data accuracy, since it might influence the monitoring equipment's correct position. Laboratory results and constraints were characterized to help better define future laboratory procedures and strategies for increasing movable bed models' accuracy and performance.
\end{abstract}

Keywords: wave basin; morphodynamic; hydrodynamic; sediment transport; cross-shore profile

\section{Introduction}

According to [1], from the 1980s onward, due to the failure of many "hard coastal engineering structures" (e.g., groins, breakwaters, or revetments), the "soft engineering" coastal protection interventions (e.g., artificial beach nourishments) became more appealing from the technical and economic point of view. However, to correctly identify the type of coastal protection to use, one must look at the causes of the problem (e.g., massive erosion and littoral drift sediment budget deficit), the morphological processes, and the safety, recreational, environmental, and economic aspects. Thus, evaluation and assessment criteria for the design and accreditation of nourishment projects are needed. Critical scientific and technical issues must be addressed prior to its development [2].

Physical modeling of coastal interventions, such as beach nourishment, helps in understanding the nourishment impacts on the beach morphodynamics and physical processes, thus assessing its performance [3]. There are several works that address 2D physical modeling in general [4,5], and more precisely, artificial nourishments [6,7]. These are usually specific to a certain sediment transport mechanism or morphological element of the beach (e.g., dune stability). However, the lack of quantitative studies related to 3D morphological evolution makes the validation of morphodynamical models and the understanding of the beach morphodynamic more difficult [8]. The present work describes 
a set of laboratory tests performed in the wave tank at the Faculty of Engineering of the University of Porto, in the laboratory of the Hydraulics, Hydraulic Resources, and Environment Section (SHRHA) between the 23rd September and the 23rd December 2016. It was intended to obtain hydrodynamic, sediment transport, and morphodynamic data concerning the performance of artificial nourishments (Scenario A).

This work also aims to increase knowledge related to 3D movable bed physical modeling, with special focus on the required setup and configuration of the experiments and monitoring procedures, in order to obtain tangible data that allow the proper assessment of the nourishment morphological, hydrodynamic, and sediment transport impact. A generic beach was modeled, taking into consideration the laboratory's available equipment and constraints. Sediment size, available sand quantities, existing monitoring equipment, wave basin dimensions, and the wave generators' capacity were the main aspects taken into consideration to characterize the beach and define the laboratory tests. Cross-shore and longshore velocities and suspended sediment concentrations were also monitored to assess the impact of the nourishment in an equilibrium beach. The main topics discussed are related to the model's hydrodynamic and morphodynamic behavior and constraints in preparing and testing a physical model with a movable bed. Constraints are mainly related to the monitoring of the morphological evolution of the bed, hydrodynamic phenomena in the wave basin, sediment transport quantification, and monitoring instruments' locations.

\subsection{Artificial Nourishments}

According to [9], beaches offer storm protection through a natural dynamic response to changing incoming waves and water levels. According to [7,10-12], shoreface nourishments, involving submerged mounds of sediments, appear to be a good alternative to hard engineering coastal defense structures (incorporating elements of efficiency, ecology, and operating cost). According to [13], the primary objective of beach nourishment is the protection of upland structures and infrastructures. It is often related to protection of seawalls and revetments against local scour, strengthening of dunes and beaches in order to maintain the coastline position, dune width extension for protection against floods, compensation of downdrift erosion due to coastal defense structures (e.g., groins), and enhancing recreation at a small scale [2,14-16]. To design an artificial nourishment, a crossshore profile needs to be defined. A common assumption is that after nourishment, the profile shape will evolve towards its initial shape (provided that the same type of sediments has been used), so the final geometric result should be similar to the initial one before the filling. There is a need for maintenance (post-storm and periodic) to guarantee the desired protection level [13]. Usually, artificial nourishments are designed for a time scale of tens of years, considering a periodic (re)nourishment from 3 to 5 years after construction or renourishment. Longevity is primarily determined by the degree to which the placed sand volume addresses any pre-project profile volume deficit and the rate at which fill material is transported out of the project domain in the alongshore direction (lateral and cross-shore direction spreading losses). Wave-driven longshore sand transport processes are the major cause of lateral spreading. In addition, the fill itself creates a perturbation in the shoreline and beach orientation, particularly on the up and downdrift limits of the fill. In these transitions, local wave transformation patterns and consequently the longshore sand transport regime change. Changes lead to higher rates of fill loss from the longshore limits of the project.

\subsection{Physical Modeling}

According to [17], reduced-scale physical models replicate nearshore processes, without simplifying the governing equations that characterize the involved phenomena/processes, i.e., they overcome the inherent limits of deterministic fluid mechanics due to turbulence. Physical modeling has a reduced cost and presents fewer difficulties when compared to on-site data collection [18-21]. However, working at a reduced scale implies that all relevant variables will not be correctly simulated and even some phenomena that occur in 
nature will not be modeled. The laboratory itself may also have an impact on the results. Common laboratory effects are related to the inability to create realistic forcing conditions and the influence of the presence of physical boundaries like wave basin walls [17]. When trying to reproduce a specific beach scenario, these effects limit the extrapolation of the results to the real prototype dimensions $[17,18,21]$. Considering specific physical modeling tests to evaluate nourishment interventions, the work of [7] can be referred to. [7] analyzed shoreface and bar nourishments morphodynamic, hydrodynamic, and sediment grain size distribution under storm events using a 2D physical model. Results show important insights about the nourishment cross-shore behavior. An increase in the profile steepness was observed in all the nourishments, while the shoreface nourishment was the only scenario that presented a beach width increase after a full storm cycle. Physical tests concerning artificial nourishment performance using 3D physical modeling are scarce in the literature review. [22] studied the impact of several nourishment positions and nourishment frequencies using a distorted physical model. The study was performed to identify which nourishment scenario would have a positive impact in increasing Copacabana beach (Brazil) width. Other studies concerning nearshore nourishments on 3D physical models exist, such as $[23,24]$.

\section{Laboratory Tests}

\subsection{Model Setup}

The modeled coastal stretch represents a linear beach without the presence of any coastal structures, before and after a construction of an artificial nourishment, where the main sediment transport mechanism is governed by the wave action.

SHRHA Hydraulic Laboratory wave basin has a longitudinal and cross extension of 28 and $12 \mathrm{~m}$, respectively, with a maximum depth of $1.2 \mathrm{~m}$. The laboratory is equipped with a multi-element, piston-type wave generation system that possesses an active reflection absorption system (HR Wallingford). Since the objective was to test the biggest possible beach extension, a longshore and cross-shore extension of $10 \mathrm{~m}$ was defined. The remaining $2 \mathrm{~m}$ of the total basin width was used to build a sediment collector at the downdrift limit of the basin with the objective to estimate the net longshore sediment transport volumes at the end of each tested scenario. The available sediments at the laboratory were characterized as quartz sand, with a specific mass of $2650 \mathrm{~kg} / \mathrm{m}^{3}$ and a median diameter $\left(d_{50}\right)$ of $0.27 \mathrm{~mm}$. Offshore significant wave height $\left(\mathrm{H}_{\mathrm{S}}\right)$ mean period, $\left(\mathrm{T}_{0}\right)$ peak period $\left(\mathrm{T}_{\mathrm{p}}\right)$, and wave length $\left(\mathrm{L}_{0}\right)$ were, respectively, $12.5 \mathrm{~cm}, 1.63 \mathrm{~s}, 2.13 \mathrm{~s}$, and $3.97 \mathrm{~m}$. Despite not trying to reproduce a specific prototype situation, these parameters were defined based on the Northwest Portuguese Coast characteristics (sediments and waves) considering a geometric scale of about 1:20, obtained through Froude similarity. A JONSWAP Spectrum was used (Equations (1) and (2), with $f_{p}$ being the peak frequency and $f$ representing the possible frequencies), with shape parameters $\gamma$ and $\sigma$ of 3.3 and 0.08 , respectively, and $\alpha=0.2189$ [20]. The mean water surface at the wave tank was kept constant during the laboratory tests.

$$
\begin{gathered}
E(f)=\alpha g^{2}(2 \pi)^{-4} f^{-5} \exp \left(-1.25\left(f / f_{p}\right)^{-4}\right) \gamma^{r} \\
r=\exp \left(-0.5\left(\left(f / f_{p}-1\right) / \sigma\right)^{2}\right)
\end{gathered}
$$

The initial cross-shore beach profile is characterized by an emerged slope $(\beta)$ and length $\left(l_{\mathrm{e}}\right)$ of 0.03 and $4 \mathrm{~m}$, respectively, and a height of $12 \mathrm{~cm}$. The submerged part is described by Dean's [25] profile: $h=A \times y^{m}$. A value of 2/3 was chosen for the " $\mathrm{m}$ " parameter (intermediate beach), while the " $\mathrm{A}$ " parameter is obtained through [17] formulation. This formulation leads to an average steeper profile at the surf zone, but it allows respecting the $10 \mathrm{~m}$ cross-shore profile extension. The initial cross-shore profile geometry influences the initial rate of morphologic beach changes, since the further from equilibrium the initial beach geometry is, the more changes it will suffer. At the prototype scale, the cross-shore profile geometry would have been characterized by the same " $\mathrm{A}$ " and " $\mathrm{m}$ " parameters, since the model is designed to be geometrically non-distorted. 
The profile has a submerged length $\left(l_{\mathrm{s}}\right)$ of $6 \mathrm{~m}$ that develops towards a total depth of $0.4 \mathrm{~m}$ (defined through Roberts' [26] formulation 27), which corresponds to the closure depth $\left(\mathrm{d}_{\mathrm{c}}\right)$ and the adopted maximum offshore depth, giving the profile a total height $\left(\mathrm{h}_{\mathrm{t}}\right)$ of $52 \mathrm{~cm}$ (Figure 1), with a slope $(\beta)$ of 0.03 . The total cross-shore extension of the beach was of $10 \mathrm{~m}$.

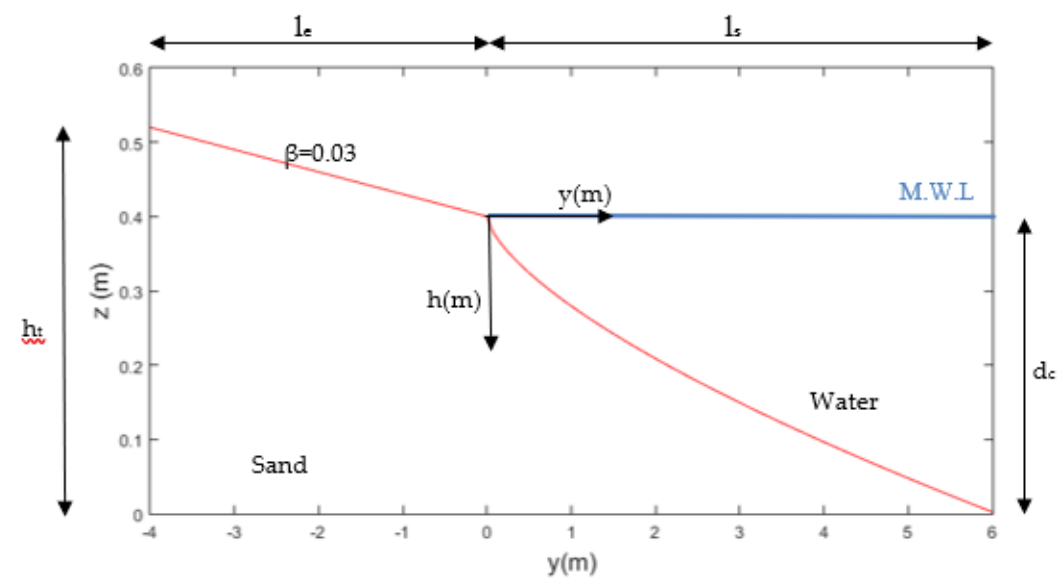

Figure 1. Initial cross-shore profile of the physical model (full extension).

The modeled beach was built over a dissipative beach to reduce the amount of sediment necessary for the model and to dissipate the wave energy propagating and breaking over the model landward limit (Figure 2). The initial low sand compaction affects the rate of the morphological cross-shore changes. An initial liquefaction of the sand was observed when filling the wave basin with water, which led to an initially higher value of the sediment transport. Additionally, no pumps were used to match the longshore current to prevent large circulation eddies.

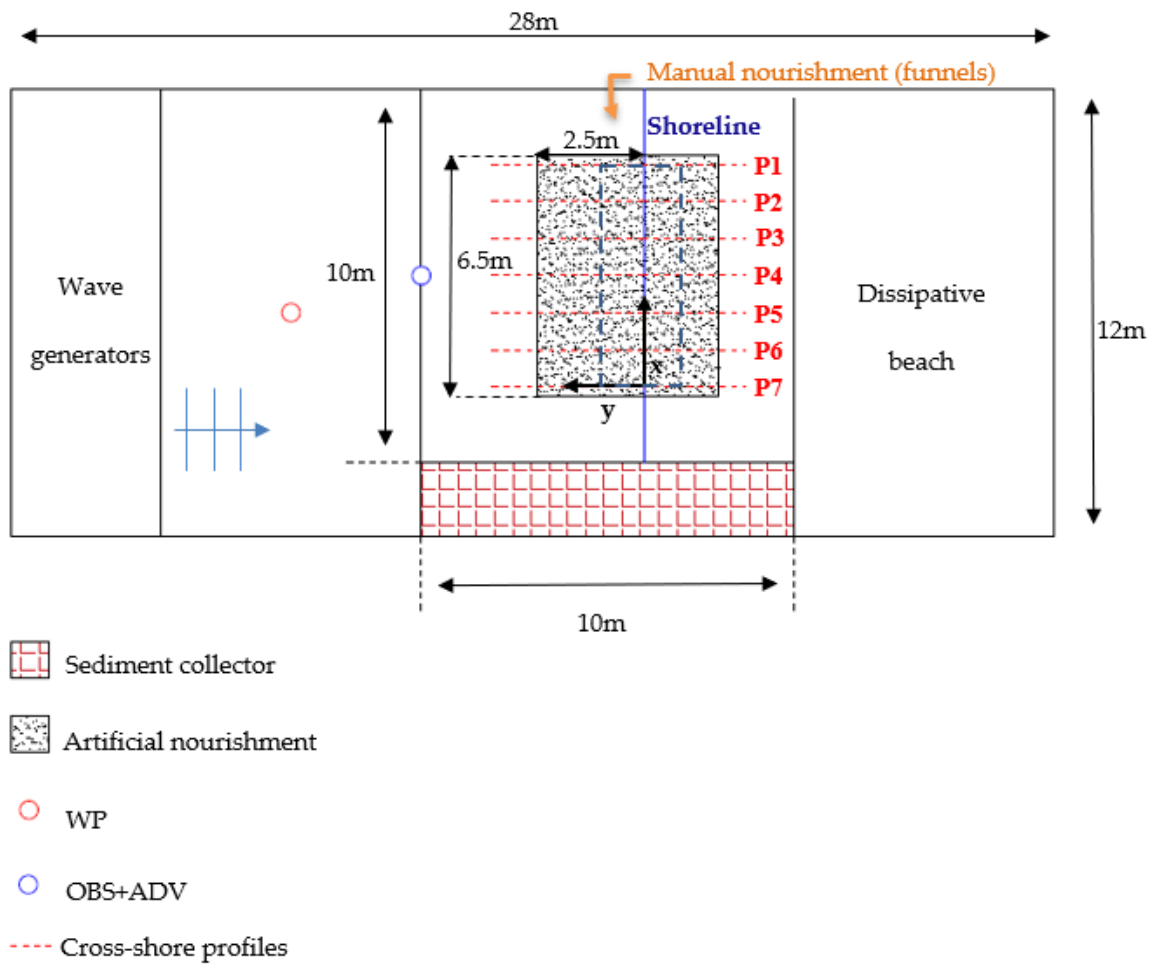

Figure 2. Beach plan scheme at the wave basin. The area represented by a blue dashed rectangle, above the nourishment, represents the monitored cell. 


\subsection{Tested Scenarios}

Two sets of experiments were performed: A.1, which aimed to find a dynamic equilibrium or near-equilibrium state of the natural beach, and A.2, where an artificial nourishment is built on the pre-existing beach (final beach of scenario A.1). Beach configuration is presented in Figures 2 and 3. Scenario A.1 had a total duration of $26.5 \mathrm{~h}$ (from $\mathrm{t}=0 \mathrm{~min}$ to $\mathrm{t}=1590 \mathrm{~min}$ ), while scenario A. 2 had a duration of $20 \mathrm{~h}$ (from $\mathrm{t}=1590 \mathrm{~min}$ to $\mathrm{t}=2790 \mathrm{~min}$ ). During the first $20 \mathrm{~h}$ (1200 min), scenario A.1 was subjected to wave action in order to guarantee that an equilibrium or near-equilibrium (static) configuration was reached by the beach and that the initial sand at the beach would be compacted. During this interval, only the initial and final profiles, at $\mathrm{t}=0 \mathrm{~min}$ and $\mathrm{t}=1200 \mathrm{~min}$, respectively, were monitored. Throughout the rest of the tests, morphological evolution of the beach was regularly monitored. The rest of scenario A.1 consisted in subjecting the beach to wave action during $6.5 \mathrm{~h}$ (from $\mathrm{t}=1200 \mathrm{~min}$ to $\mathrm{t}=1590 \mathrm{~min}$ ), while in the A.2 scenario, the beach was subjected to the already referred $20 \mathrm{~h}$ of wave action.

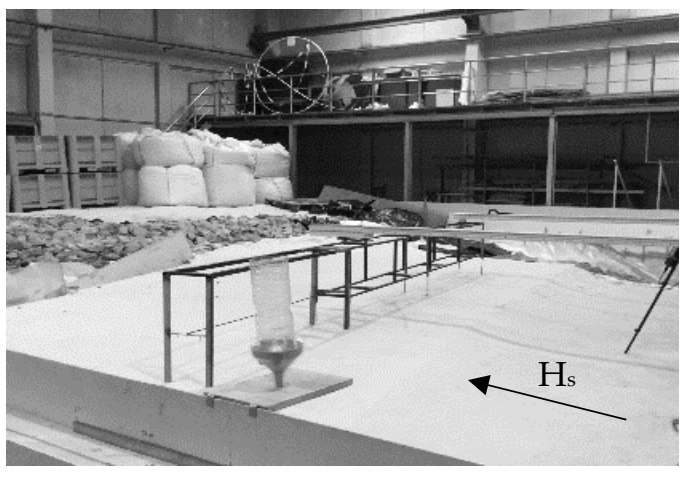

(a)

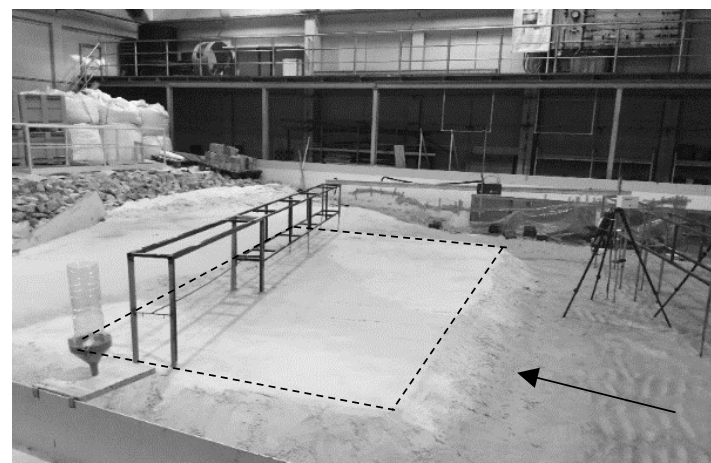

(b)

Figure 3. Initial beach configurations for both scenarios (the dashed lines represent the top limits of the nourishment emerged dimensions): (a) Initial beach before nourishment (Scenario A.1); (b) Initial nourished beach (Scenario A.2).

To simulate the littoral drift, sediments were continuously added at the updrift beach boundary to create a perturbation in the bathymetry that could induce a longshore sediment transport due to an alteration in the shoreline and bathymetric orientation with the wave direction. Sediments were added to the basin near the updrift wall, by manual nourishment, using 5 funnels placed at different distances from the initial shoreline position (Table 1 and Figure 3). Each funnel's opening was calibrated to feed the same amount of sediment at a constant flow rate of $48 \mathrm{~kg} / \mathrm{h}$. This value was estimated accordingly to [20] in order to simulate the littoral drift. At $\mathrm{t}=1200 \mathrm{~min}$, the beach reached an equilibrium with no significant changes in the shoreline position being recorded during the last hour of tests.

Table 1. Scenario A.1, funnels' position. Cross-shore distances to the initial shoreline.

\begin{tabular}{cccccc}
\hline Funnels & $\mathbf{1}$ & $\mathbf{2}$ & $\mathbf{3}$ & $\mathbf{4}$ & $\mathbf{5}$ \\
\hline Distance to the initial shoreline $(\mathrm{m})$ & 2.92 & 2.42 & 1.92 & 1.42 & 0.42 \\
\hline
\end{tabular}

The funnels used to simulate the littoral drift represent a discrete supply of sediments. Despite being evenly spaced, they do not cover the entire active cross-shore extension and are focused on supplying the most energetic area where wave breaking is observed. This reproduces neither a real cross-shore distribution of the longshore sediment transport in natural conditions nor the spatial continuity of the littoral drift.

Regarding the downdrift sediment losses, accumulated in the sediment trap, those volumes were only measured at the end of each scenario, since in order to measure them, 
the wave tank had to be emptied. Therefore, those values were only used to estimate the total average longshore sediment transport rates in each scenario.

During the last $6.5 \mathrm{~h}$ of scenario A.1 (from $t=1200 \mathrm{~min}$ to $t=1590 \mathrm{~min}$ ) and over the full duration of scenario A.2 ( $20 \mathrm{~h}$, from $t=1590 \mathrm{~min}$ to $t=2790 \mathrm{~min})$, the wave generator system and monitoring devices were stopped periodically to measure the bathymetry using the HR Wallingford profiler. The stopping instants are represented by dashed lines in Figures 4-6 and the following ones, being more frequent at the early stages of each set of tests. There was no need to empty the tank, since the profiler had a mechanical probe.

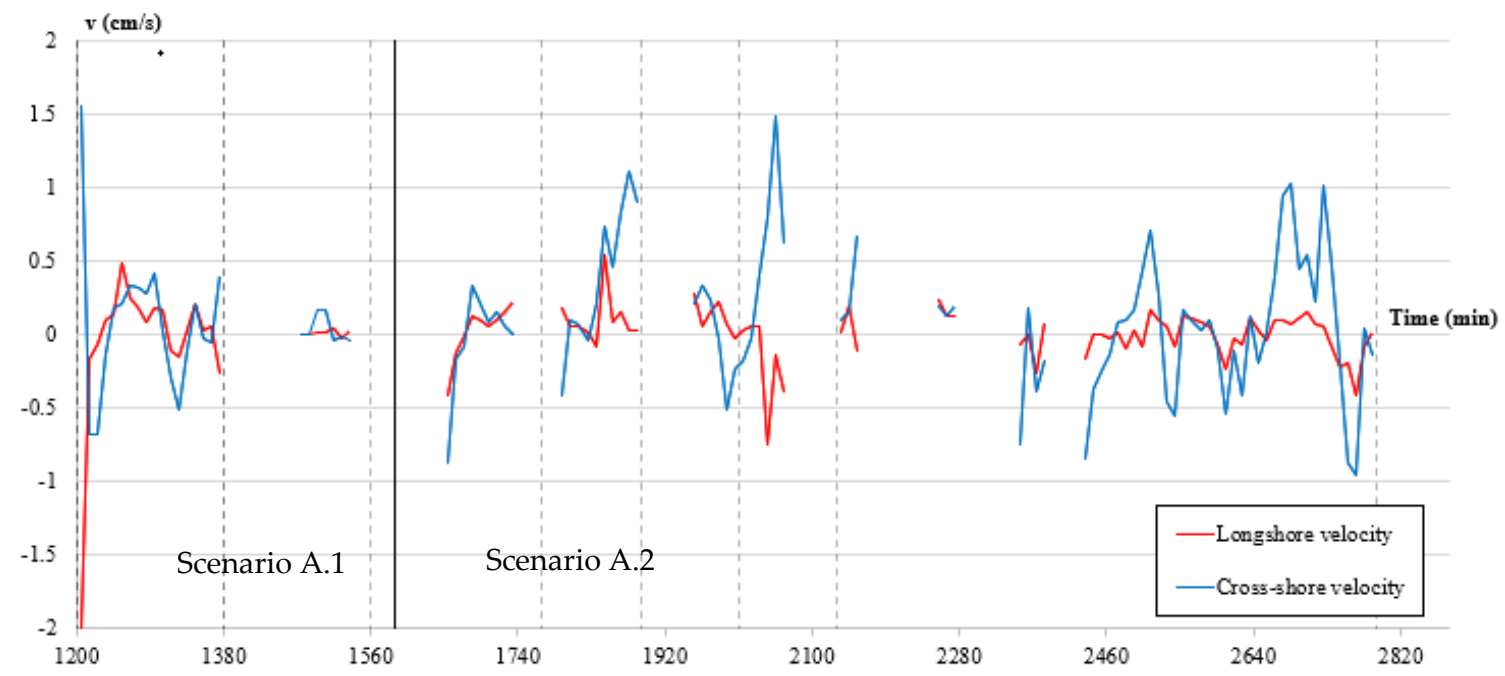

Figure 4. Recorded data timeline for the longshore and cross-shore velocity for the A.1 and A.2 scenarios. The vertical black line represents the transition between scenarios A.1 and A.2. The ver-tical black dashed lines represent the instants when the equipment was stopped.

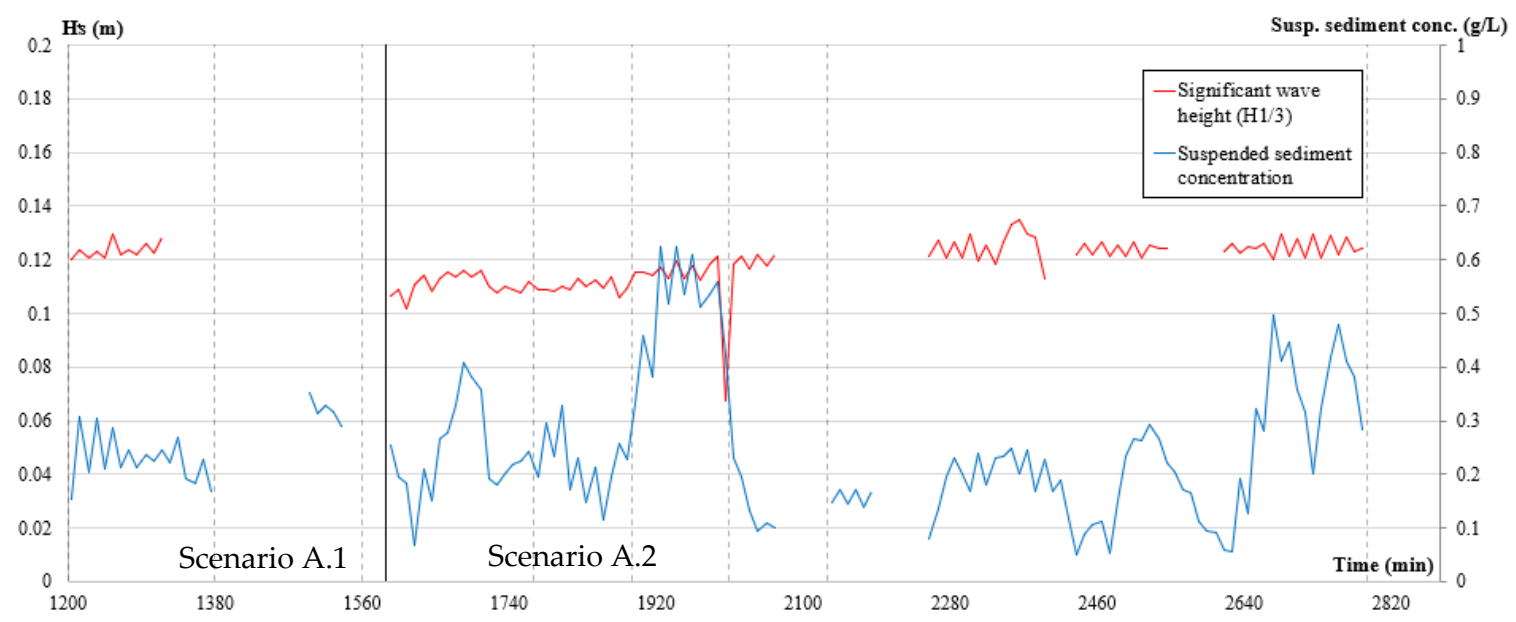

Figure 5. Recorded data timeline for significant wave height and suspended sediment concentration for the A.1 and A.2 scenarios. The vertical black line represents the transition between scenarios A.1 and A.2. The vertical black dashed lines represent the instants when the equipment was stopped. 


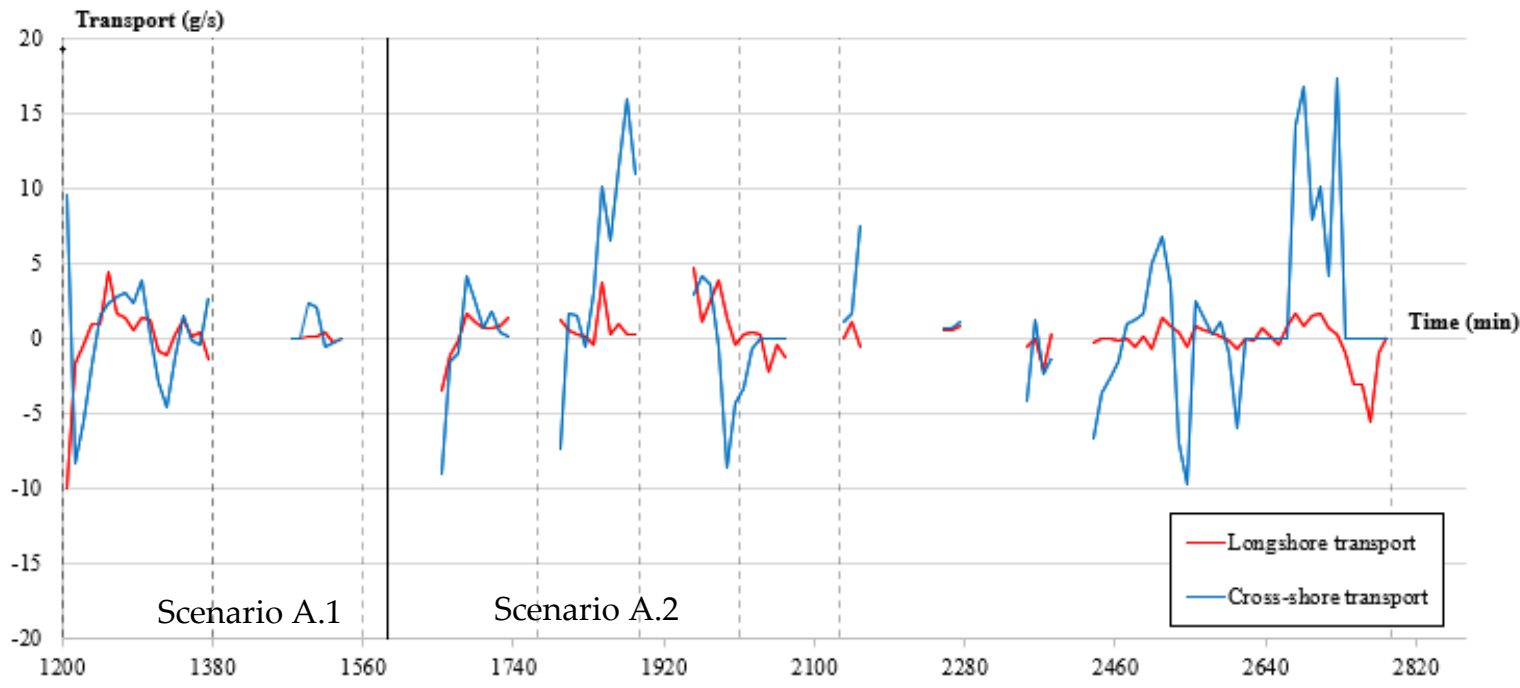

Figure 6. Timeline for the estimated suspended longshore and cross-shore sediment transport. The vertical black line represents the transition between scenarios A.1 and A.2. The vertical black dashed lines represent the instants when the equipment was stopped.

The nourishment was designed to increase the beach width by $2.5 \mathrm{~m}$, with a flat emerged surface intercepting the existing beach slope, with a longshore extension of $6.5 \mathrm{~m}$ (see Figures 2 and 3). The nourishment configuration placed over the modeled beach led to the use of a total amount of $9080 \mathrm{~kg}$ of sand for its construction.

\subsection{Equipment}

One acoustic Doppler velocimeter (SONTEK $10 \mathrm{MHz}$ ADV), one optical backscatter (OBS $3+$ ), and one wave probe (WP) were used to monitor flow velocity components, suspended sediment concentrations, and wave heights and periods, respectively. The location of these instruments in the wave basin is shown in Figure 2. An HR Wallingford profiler was used to monitor 7 cross-shore profiles (P1 to P7), spaced $1 \mathrm{~m}$ apart (middle profile, $\mathrm{P} 4$, was centered on the beach longshore extension). Due to its limited length, the profiler monitored $2 \mathrm{~m}$ of the cross-shore extension of the profile. Thus, a total longshore and cross-shore extension of 6 and $2 \mathrm{~m}$, respectively, was monitored.

Preparation of physical tests with movable beds presents some specific procedures. One of the main struggles in preparing the laboratory tests was related to the definition of the instrument's location. Due to the morphodynamic evolution during the tests, the shoreline position over time will change and the equipment will measure different locations on the profile. Thus, the relative positions of the instruments vary with increasing or decreasing cross-shore profile width. Additionally, bed accretion could cause misreading due to the risk of the monitored sample not being positioned in the water column.

Due to the morphological evolution uncertainty, plus the fact that an artificial nourishment was built to increase the beach width, it was chosen to place the ADV and the OBS at the offshore limit, aligned with the middle cross-shore profile (P4). The measured sample, for both pieces of equipment, was initially positioned $10 \mathrm{~cm}$ above the model bed. The WP was placed in the middle of the wave basin to measure the incoming wave's characteristics. Sampling frequencies for the OBS, ADV, and WP were 5, 25, and $25 \mathrm{~Hz}$, respectively.

Since the OBS received signal is influenced by the size, composition, and shape of the suspended sediments, it was previously calibrated using sediments from the laboratory. ADV data quality is defined by the signal to noise ratio (SNR) and correlation. The lowest possible values for SNR and correlation were selected based on the instrument's manual [27] and on the works of [28,29]. The values of $15 \mathrm{~dB}$ and $70 \%$ were chosen for the lowest admissible limit of SNR and correlation, respectively. 
The profiler allowed the collection of only $2 \mathrm{~m}$ of the profile cross-shore extension $(6 \mathrm{~m})$. This increases the difficulty in the data analysis, since it was not possible to precisely track the cross-shore sediments' movement over time, over the full extension of the beach for both longshore and cross-shore directions. In the situation that the cross-shore profile increases its length towards offshore (e.g., due to an undertow current), leading to an increase in the beach extension, the bathymetric data reduces its representability regarding the beach morphological evolution.

\section{Results}

\subsection{Hydrodynamic and Sediment Transport}

The hydrodynamic and sediment transport collected data, for both scenarios A.1 and A.2, are presented in Figures 4-6. Figure 4 shows the longshore and cross-shore flow velocity components, obtained by the ADV (negative values are considered in the direction of the sediment collector and towards offshore, respectively, for longshore and cross-shore velocity components). Significant wave height (based on WP records) and suspended sediment concentrations (OBS records) are presented in Figure 5, while Figure 6 shows the suspended longshore and cross-shore sediment transport rates estimated based on flow velocities and suspended sediment concentrations. The total longshore suspended sediment transport was estimated by the combination of the longshore velocity rates and suspended sediment concentrations. The concentration and velocity values were assumed constant throughout the water column $(0.4 \mathrm{~m})$ and over the cross-shore extension of the active profile (a total extension of $8 \mathrm{~m}$ ) to estimate the net transport. For the cross-shore transport, the cross-shore velocities were used instead and were assumed constant over the water column $(0.4 \mathrm{~m})$ and longshore extension of the beach $(10 \mathrm{~m})$.

The values represent an average over $10 \mathrm{~min}$ of collected data. Gaps in the velocities and suspended sediment concentration data series, with a duration inferior to $2 \mathrm{~s}$, were filled by linear interpolation, and those with a duration superior to $2 \mathrm{~s}$ were kept empty. Since a qualitative analysis was intended, these gaps might still allow the overall analysis of the hydrodynamic and sediment transport evolution throughout the tests. Wave climate records were not subjected to any kind of filling. All the data were processed and analyzed using MATLAB.

Though it was intended for the significant wave height to be $12.5 \mathrm{~cm}$ for both experiments, the significant wave height in scenario A.2, during the first $540 \mathrm{~min}$, is on average about $10.5 \%$ smaller than $12.5 \mathrm{~cm}$, corresponding to $11.2 \mathrm{~cm}$. This was due to the beach nourishment morphology evolution and thus a correction of the gain factor in the wave generation and active dissipation system was performed during this time interval to achieve the expected wave heights.

Over the full duration of the laboratory tests, several rip-currents were observed; however, their position was not monitored. The presence of rip-currents' presence combined with the water recirculation and local bathymetric changes (near the ADV) are responsible for the registered alteration of velocities sign/direction.

Longshore velocities present a range between -0.75 and $0.55 \mathrm{~cm} / \mathrm{s}$, while cross-shore velocities present a larger range, from -0.95 to $1.55 \mathrm{~cm} / \mathrm{s}$. The average longshore and cross-shore velocities were approximately -0.05 and $0.08 \mathrm{~cm} / \mathrm{s}$ for A.1 scenario and 0.01 and $0.11 \mathrm{~cm} / \mathrm{s}$ in scenario A.2, respectively.

Suspended concentration time series shows a nearly constant value of $0.25 \mathrm{~g} / \mathrm{L}$ during A.1, while in A.2 a larger variability is present, with higher values of concentration from $t=1890 \mathrm{~min}$ to $t=2010 \mathrm{~min}$ and from $t=2610 \mathrm{~min}$ to $t=2790 \mathrm{~min}$. Due to the nourishment, in scenario A.2, a higher average value of the suspended sediment concentration than scenario A.1 was recorded. The suspended sediment concentration peak was not registered immediately after the nourishment, as would be expected due to the large perturbation and the lack of sand compaction. The highest value of suspended sediment concentration of $0.60 \mathrm{~g} / \mathrm{L}$ was recorded in scenario A. 2 between $\mathrm{t}=1890 \mathrm{~min}$ and $\mathrm{t}=2010 \mathrm{~min}$, about $300 \mathrm{~min}$ after the start of the laboratory tests for scenario A.2. This 300 min delay in the 
recorded suspended sediment concentrations peak during scenario A.2 might be explained by the distance of the OBS to the shoreline and the nourishment area (and the eventual influence of the re-circulation currents inside the basin).

Over the last $6.5 \mathrm{~h}$ of scenario A.1 (from $t=1200 \mathrm{~min}$ to $t=1590 \mathrm{~min}$ ), an average value of $0.23 \mathrm{~g} / \mathrm{s}$ in the direction of the sediment collector (with an absolute maximum peak of $9.92 \mathrm{~g} / \mathrm{s}$ ) and $0.35 \mathrm{~g} / \mathrm{s}$ in the offshore direction (with an absolute maximum of $14.39 \mathrm{~g} / \mathrm{s}$ ) was obtained for the longshore and cross-shore suspended transport rates, respectively. During scenario A.2, the maximum value of longshore and cross-shore suspended sediment transport rate of 7.68 and $17.36 \mathrm{~g} / \mathrm{s}$, respectively, was obtained between $360 \mathrm{t}=2130 \mathrm{~min}$ and $t=2790$ min (last $11 \mathrm{~h}$ hours of tests during scenario A.2). In scenario A.2, the mean suspended longshore transport rate inverted its direction (in the funnel direction) and decreased its magnitude to $0.08 \mathrm{~g} / \mathrm{s}$, while the cross-shore suspended transport rate increased to $0.98 \mathrm{~g} / \mathrm{s}$ (towards offshore). Therefore, while the suspended cross-shore transport is, on average, towards offshore, between scenarios A.1 and A.2, the average longshore transport changes direction (Table 2).

Table 2. Suspended sediment transport rates $(\mathrm{g} / \mathrm{s})$.

\begin{tabular}{ccccccc}
\hline & \multicolumn{2}{c}{ Maximum Positive } & \multicolumn{2}{c}{ Maximum Negative } & \multicolumn{2}{c}{ Average } \\
\hline Scenario & Longshore & Cross-Shore & Longshore & Cross-Shore & Longshore & Cross-Shore \\
\hline A.1 & 4.46 & 11.42 & -9.92 & -14.39 & -0.23 & 0.35 \\
A.2 & 7.68 & 17.36 & -6.66 & -15.49 & 0.08 & 0.98 \\
\hline
\end{tabular}

The total longshore net sediment transport value was estimated considering the accumulated sediments collected downdrift. At the end of scenarios A.1 and A.2, a total value of about 7630 and $7560 \mathrm{~kg}$ of sand was collected downdrift, respectively. The value obtained for scenario A.1 takes into consideration all the $1590 \mathrm{~min}$ of tests. A mean net transport rate of approximately $288 \mathrm{~kg} / \mathrm{h}(80 \mathrm{~g} / \mathrm{s})$ for scenario A. 1 and $378 \mathrm{~kg} / \mathrm{h}$ $(105 \mathrm{~g} / \mathrm{s})$ for scenario A.2 was obtained from the total sand volumes accumulated downdrift. Estimated sediment transport rates are much higher than the $48 \mathrm{~kg} / \mathrm{h}$ added by the funnels. Although these values indicate a general retreat of the shoreline, they do not correctly characterize the sediment transport, since the initial conditions of the sand compaction do not reproduce the ideal condition to be modeled. By extrapolating the obtained results from the offshore monitoring point to the full extension of the beach (including the surf zone), it can be concluded that the bedload transport dominates the sediment transport for the modeled conditions.

\subsection{Morphodynamics}

Seven cross-shore profiles spaced $1 \mathrm{~m}$ apart and with an extension of $2 \mathrm{~m}$ were monitored. Figure 7 presents a digital model terrain of the modeled beach that was obtained by triangulation using a linear interpolation method and Figure 8 presents the corresponding erosion/accretion maps. The horizontal coordinate for $\mathrm{y}=0 \mathrm{~m}$ represents the initial shoreline position, which corresponds to the interception of the water level at $\mathrm{z}=0.4 \mathrm{~m}$ with the modeled beach. Figure 7 shows a shoreline retreat and slope decrease between the initial and final conditions in both A.1 and A.2 scenarios. 


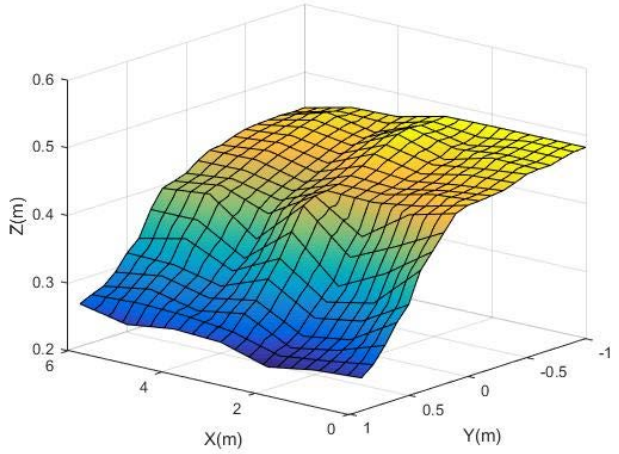

(a)

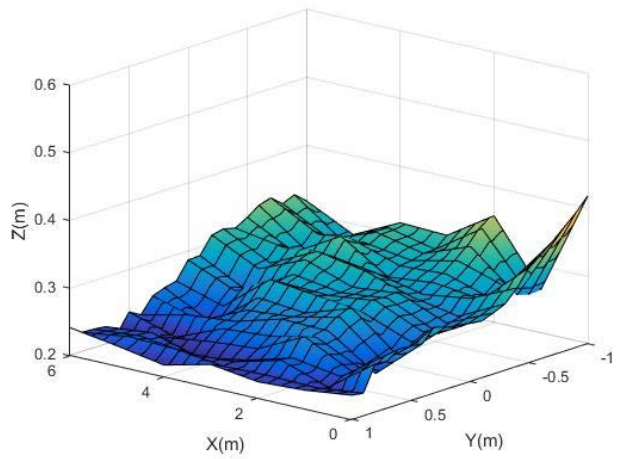

(c)

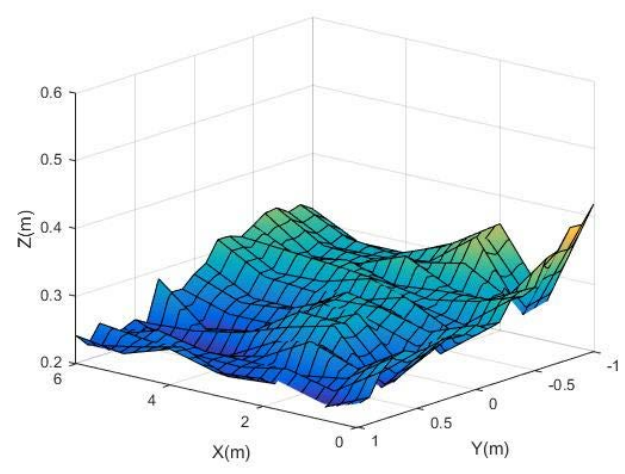

(e)

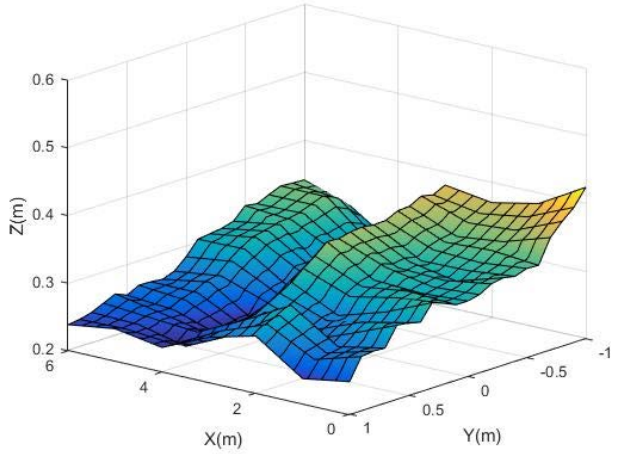

(b)

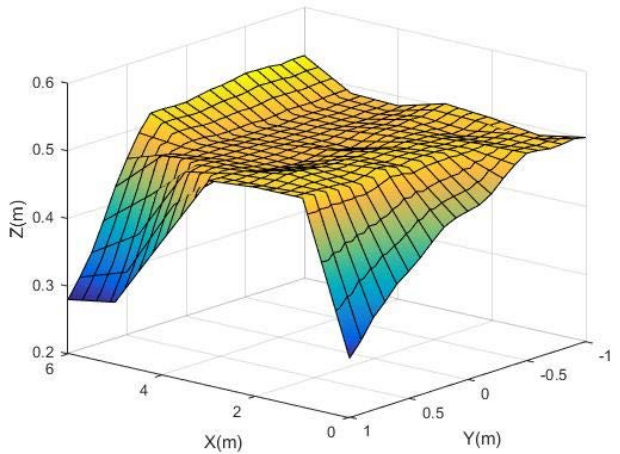

(d)

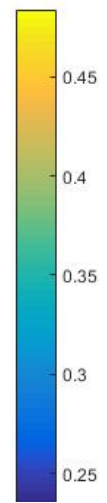

Figure 7. Bathymetric and topographic digital model terrain of the beach over the laboratory tests: (a) $\mathrm{t}=0 \mathrm{~min}$; (b) $\mathrm{t}=1200 \mathrm{~min}$; (c) $\mathrm{t}=1590 \mathrm{~min}$; (d) $\mathrm{t}=1590 \mathrm{~min}$ (A.2); (e) $\mathrm{t}=2790 \mathrm{~min}$. 


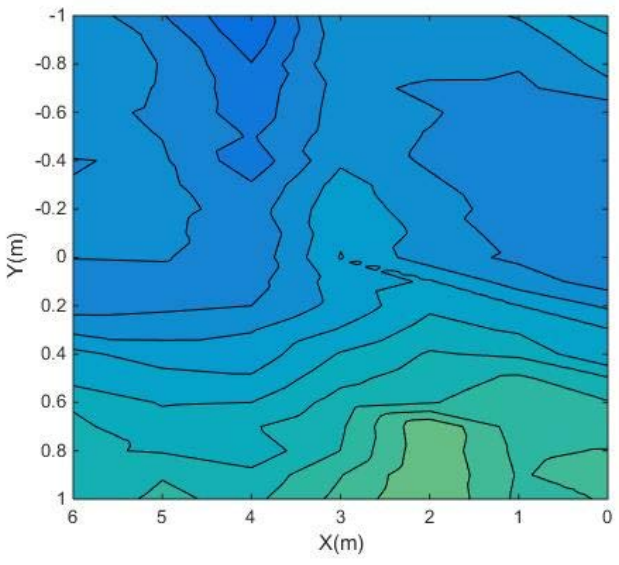

(a)

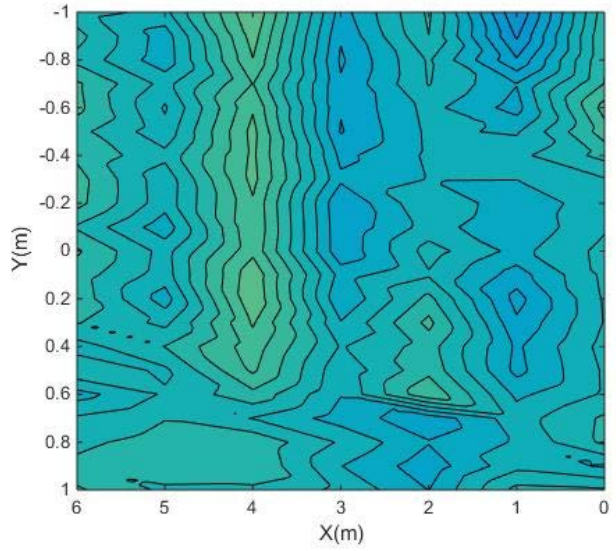

(c)

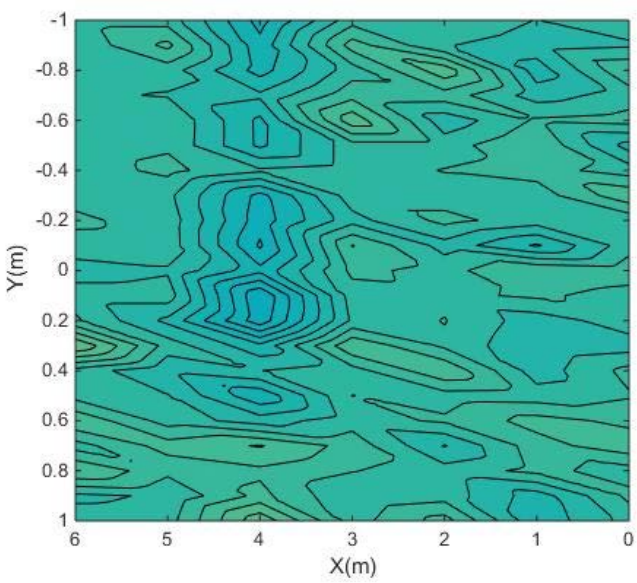

(e)

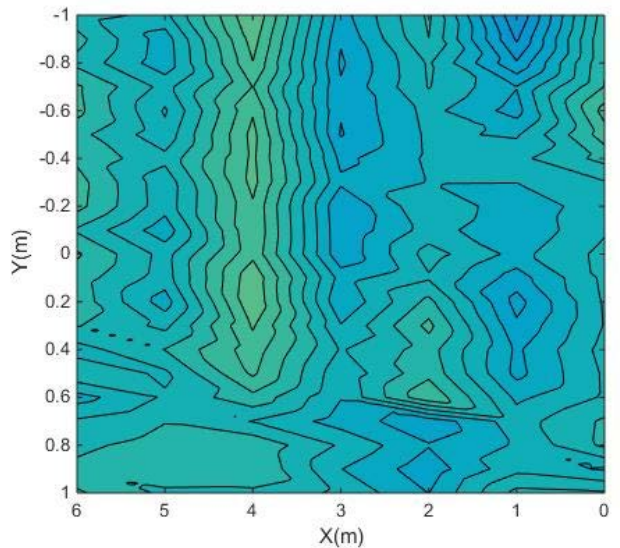

(b)

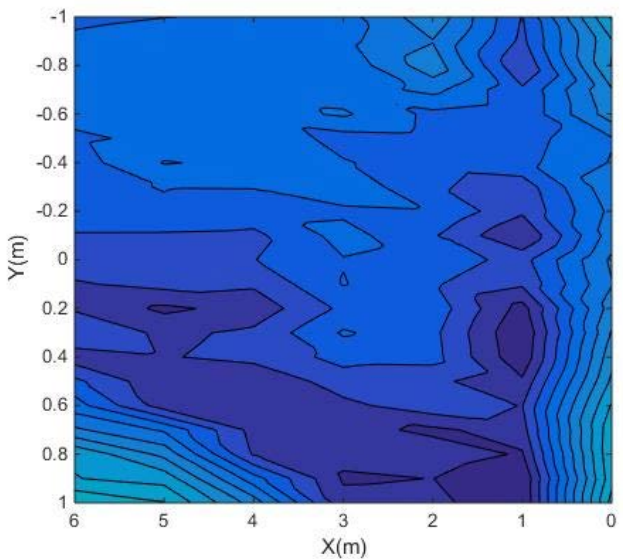

(d)

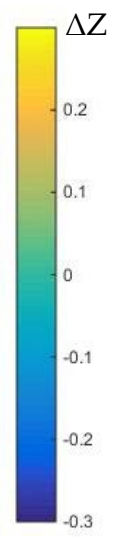

Figure 8. Erosion and accretion maps of the monitored area: (a) comparison between $t=0$ min and $t=1200 \mathrm{~min}$; (b) comparison between $t=1200 \mathrm{~min}$ and $t=1590 \mathrm{~min}$; (c) comparison between $t=1590 \mathrm{~min}(\mathrm{~A} .1)$ and $t=1590 \mathrm{~min}(\mathrm{~A} .2$ ); (d) comparison between $\mathrm{t}=1590 \mathrm{~min}(\mathrm{~A} .2)$ and $\mathrm{t}=2790 \mathrm{~min}$; (e) comparison between $\mathrm{t}=1590 \mathrm{~min}(\mathrm{~A} .1)$ and $\mathrm{t}=2790 \mathrm{~min}$.

During the first 1200 min of scenario A.1, there was a large erosion of the emerged beach, with sediments moving towards offshore, considering the lower compaction and initial adaptation of the beach profile (Figure 8 ). This tendency was also observed between 1200 and $1590 \mathrm{~min}$. The deepening of the cross-shore profile at $\mathrm{x}=4 \mathrm{~m}$ (P5) may arise due to a strong $\mathrm{Z}(\mathrm{m})$ rip-currents observed at this location. From the bathymetric data acquired during scenario A.2, a total erosion of the nourishment volume was registered 
and a bed morphological configuration similar to the end of scenario A.1 was observed. Erosion and accretion volumes' variation, presented in detail in Table 3, show that every scenario recorded mainly erosion, despite the artificial nourishment construction, as seen in Figure $8 \mathrm{c}$. Comparing Figure $8 \mathrm{c}, \mathrm{d}$, it can be observed that the artificial beach nourishment volume disappeared, since the range of vertical accretion (defined by the color range) is symmetric between both figures, and the contour line shapes are similar. A few differences are shown in Figure 8e between the end of scenario A.1 and scenario A.2, with a total difference in the beach volume of $-0.03 \mathrm{~m}^{3}$. When comparing the final beach of each scenario, a similar bottom configuration is observed (Figure $7 \mathrm{c}, \mathrm{e})$. The results show that the beach tends to an equilibrium that is independent of the nourishment performed and allows the estimation of the time scale of the nourishment existence.

Table 3. Erosion and accretion volumes at the monitored area.

\begin{tabular}{cccc}
\hline Time Interval $(\mathbf{m i n})$ & Erosion $\left(\mathbf{m}^{\mathbf{3}}\right)$ & Accretion $\left(\mathbf{m}^{\mathbf{3}}\right)$ & Balance $\left.\mathbf{( m}^{\mathbf{3}}\right)$ \\
\hline $0-1200$ & 1.06 & 0.03 & -1.03 \\
$1200-1590$ (A.1) & 0.37 & 0.02 & -0.35 \\
1590 (A.1)-1590 (A.2) & 0.00 & 2.56 & +2.56 \\
1590 (A.2)-2790 & 2.58 & 0.00 & -2.58 \\
1590 (A.1)-2790 & 0.06 & 0.03 & -0.03 \\
Total & 4.07 & 2.64 & -1.43 \\
\hline
\end{tabular}

Figure 9 represents the position of the bathymetric contour lines of the P4 profile, $\mathrm{z}=0.4 \mathrm{~m}$ and $\mathrm{z}=0.3 \mathrm{~m}$ over time. The contour for $\mathrm{z}=0.4 \mathrm{~m}$ corresponds to the shoreline and mean water lever (MWL); the $\mathrm{z}=0.3 \mathrm{~m}$ contour is represented, since the profiler was not able to monitor the complete movement of the shoreline throughout the laboratory tests. Due to the lack of available data concerning the shoreline position, it is assumed that the shoreline presents a similar behavior to the evolution of the $\mathrm{z}=0.3 \mathrm{~m}$ contour. Thus, the retreat of the $\mathrm{z}=0.3 \mathrm{~m}$ contour line was used to estimate the average retreat rates for each profile. At some instants, profile P4 intercepted the $\mathrm{z}=0.3 \mathrm{~m}$ contour twice (from $t=1020$ min till the end of scenario A.1), which indicates the presence of a bar. Different colors represent different contour lines, while the dashed lines represent a second profile interception at the same level. All the lines show a general retreat of the cross-shore profile.

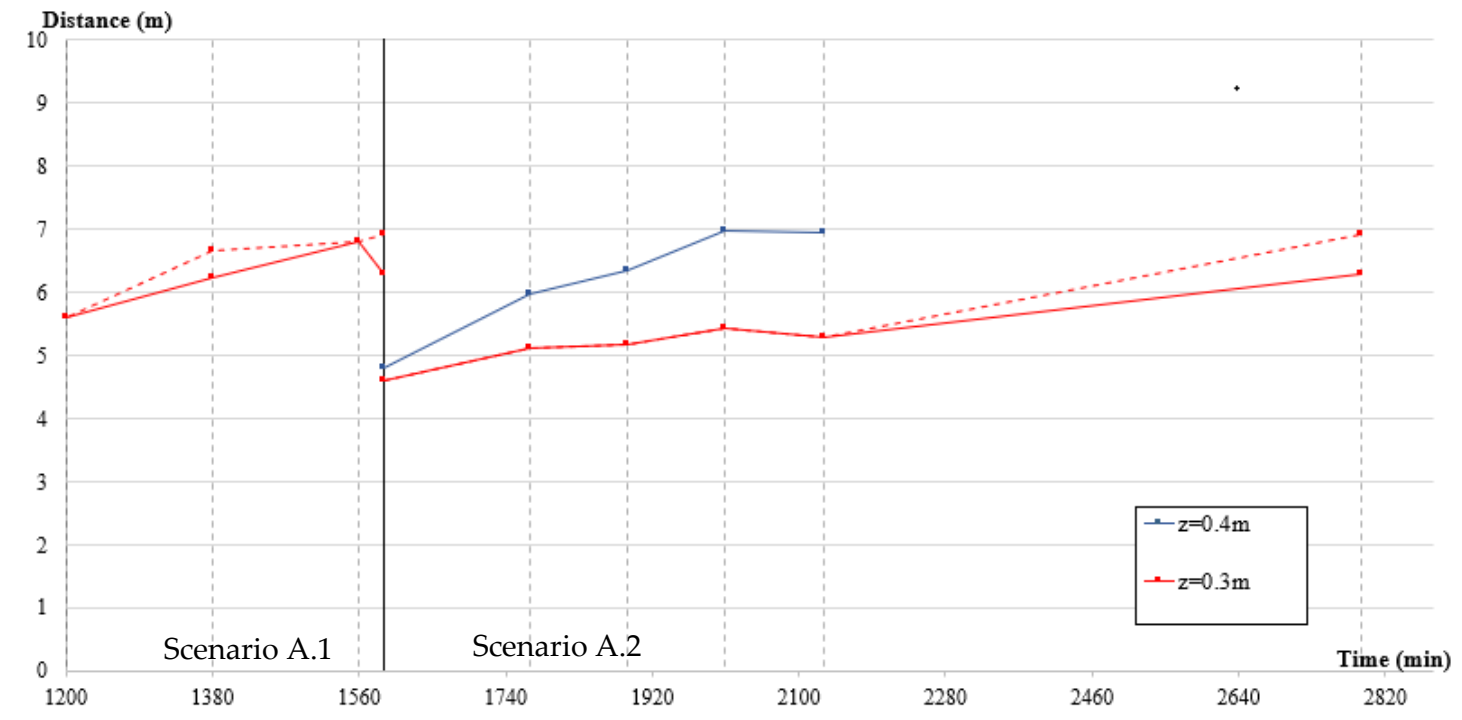

Figure 9. Timeline for profile P4 contour lines distance from the ADV. The vertical black line represents the transition between scenarios A.1 and A.2. The vertical black dashed lines represent the instants when the equipment was stopped. 
Looking at scenario A.2, the contour that corresponds to the shoreline $(\mathrm{z}=0.4 \mathrm{~m})$ shows a higher retreat rate than the contour for $\mathrm{z}=0.3 \mathrm{~m}$, as expected due to the morphological perturbance introduced by the nourishment. According to Table 4, on average, all the profiles presented a retreat of the $0.3 \mathrm{~m}$ contour for both scenarios (between 1200 and $1590 \mathrm{~min}$, in A.1 and between 1590 and $2790 \mathrm{~min}$, in A.2). On average, and considering all the profiles, scenario A.2 has a higher retreat rate than scenario A.1. It was expected for the nourishment scenario to possess higher retreat rates than scenario A.1, due to an initial loss of sand and the fact that the new profile was further away from the equilibrium or nearequilibrium configuration $[8,30]$. Nevertheless, not all the profiles in scenario A.2 recorded a higher retreat than the respective profiles for scenario A.1 (Table 4); on the profiles other than P2 and P3, the average rate is lower for A.2 scenario. The more updrift of the nourishment the profiles are, the higher the shoreline retreat rate is. The results in Figure 9 also show that the position of the shoreline in scenario A.2 is not located as offshore as in scenario A.1, which can be interpreted as a direct benefit from the nourishment performed.

Table 4. Average retreat rates $(\mathrm{cm} / \mathrm{min})$ for $\mathrm{z}=0.3 \mathrm{~m}$ contour.

\begin{tabular}{ccc}
\hline Profile & Scenario A.1 & Scenario A.2 \\
\hline P1 & 0.21 & 0.14 \\
P2 & 0.02 & 0.26 \\
P3 & 0.06 & 0.29 \\
P4 & 0.18 & 0.14 \\
P5 & 0.21 & 0.04 \\
P6 & 0.00 & 0.06 \\
P7 & 0.24 & 0.06 \\
Average & 0.13 & 0.14 \\
\hline
\end{tabular}

Considering the geometric evolution of the seven cross-shore profiles, an estimation of beach volume and beach volume variation between these seven profiles was made (Figure 10), with the coastal cell volume being defined as the volume between the horizontal contour of $\mathrm{z}=0 \mathrm{~m}$ and the upper limit of the profile geometry, through a cross-shore extension of $2 \mathrm{~m}$ and a longshore extension of $6 \mathrm{~m}$. The red line represents the total sediments' volume in the measured control volume, while the blue line represents the volume variation between time instants in the monitored control volume. An almost constant erosion state is present in the monitored cell. This analysis is in accordance with the Table 3 and Figure 8 results.

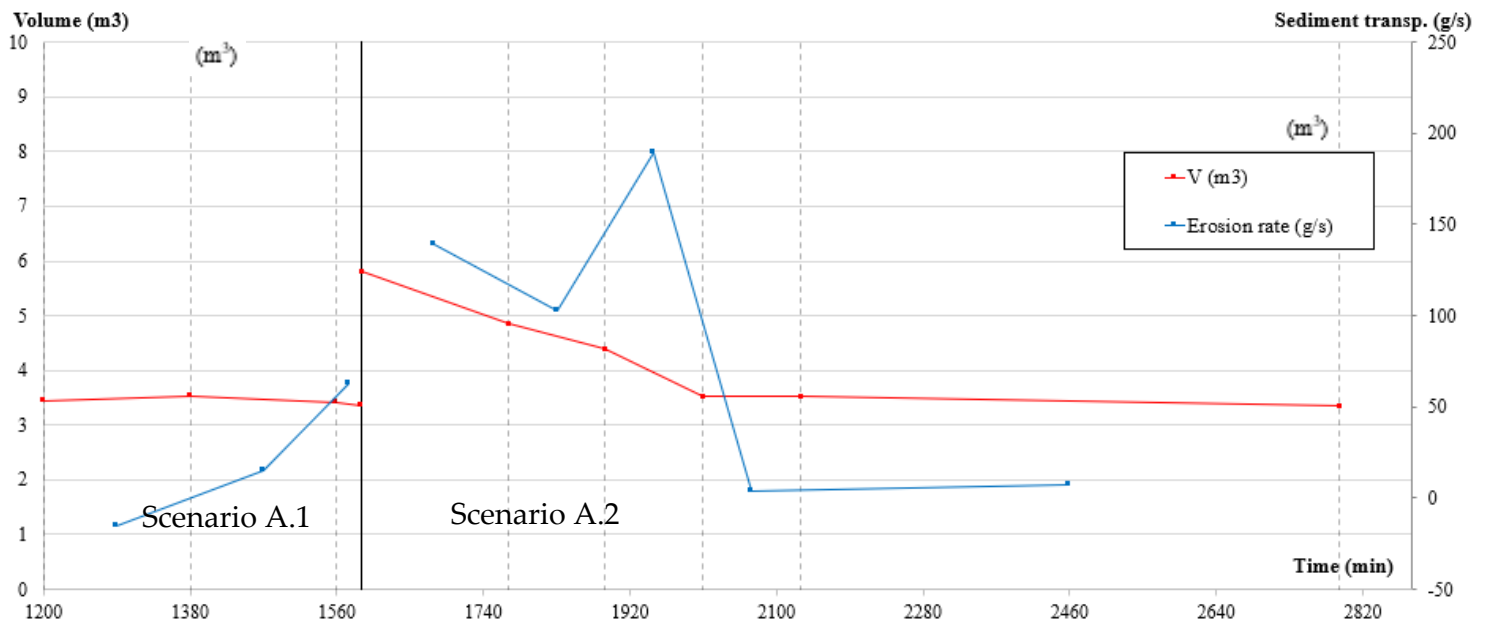

Figure 10. Timeline for beach volume variation and sediment transport volumes rate. Vertical black line represents the transition between scenarios A.1 and A.2. The vertical black dashed lines represent the instants when the equipment was stopped. 
After the beginning of scenario A.2, the artificial nourishment effect in the monitored cell had a duration of $420 \mathrm{~min}$. At the end of this time interval, the monitored cell volume reaches a value close to the volume determined at the end of scenario A.1 and the average volume variation rate goes from $0.323 \mathrm{~m}^{3} / \mathrm{h}$, during the first $420 \mathrm{~min}$, to an average value of $0.015 \mathrm{~m}^{3} / \mathrm{h}$ onwards. The volumes considered in Figure 10 can be assumed to demonstrate the nourishment impact/efficiency in the emerged beach width value, since the control volume incorporates the shoreline position after the nourishment.

Figure 11 contains the shore face slope evolution over time. The shoreface was defined as the zone between the shoreline $(z=0.4 \mathrm{~m})$ and $\mathrm{z}=0.2 \mathrm{~m}$, since there is little or no data available to the geometry of the swash zone and deeper than $z=0.2 \mathrm{~m}$. To determine the slope angle, only the top and bottom profile limits between the $\mathrm{z}=0.4 \mathrm{~m}$ and $\mathrm{z}=0.2 \mathrm{~m}$ were used. Using the classification proposed by [31] and [32], it was concluded that the mean slope of the beach described a dissipative state for scenario A.1, while for scenario A.2, despite during the tests an intermediate state was registered, the beach is also moving toward a dissipative state (slope values close to the final values for scenario A.1). For $t=1590 \mathrm{~min}$, the beach is characterized as reflective.

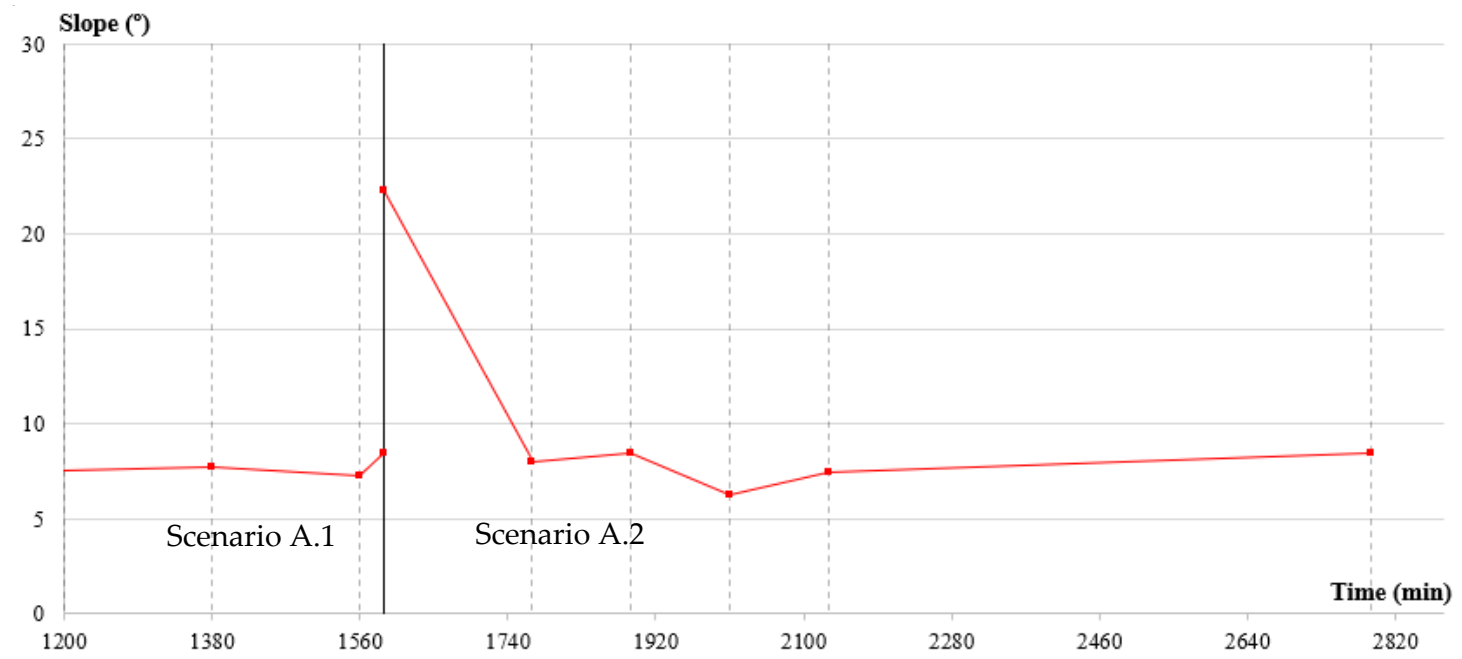

Figure 11. Timeline for mean beach shoreface slope. The vertical black line represents the transition between scenarios A.1 and A.2. The vertical black dashed lines represent the instants when the equipment was stopped.

Wave breaking mechanisms (spilling, plunging, and oscillatory) influence the crossshore distribution of the longshore sediment transport and may consequently influence the beach morphological evolution geometry and rates [33]. During scenario A.1, the wave breaking was only characterized as spilling breaking. Scenario A.2 registered plunging breaking during the first 300 min and spilling breaking afterward.

\section{Discussion}

\subsection{Sediment Transport Dynamics}

The observed variation of the cross-shore velocity in Figure 4 signal may be explained by undertow currents and bathymetric changes that change the wave breaking location and the relative position of the ADV on the cross-shore profile [34]. Bottom elevation variation near the ADV location may cause the ADV sample to be placed in a different vertical relative position in the velocity profile over time, capturing either lower and upper layers in the water column, leading to variations of the signal's direction and intensity of the recorded velocities. Scenario A presents an average suspended cross-shore sediment transport toward offshore. This effect can be observed in Figure 12, where the grid near the wave generator system, destined for emptying the basin, was initially set about $3 \mathrm{~m}$ away from the cross-shore profile limit at the beginning of the tests, while at the end, the cross-shore profile offshore limit was placed right before that same grid. 


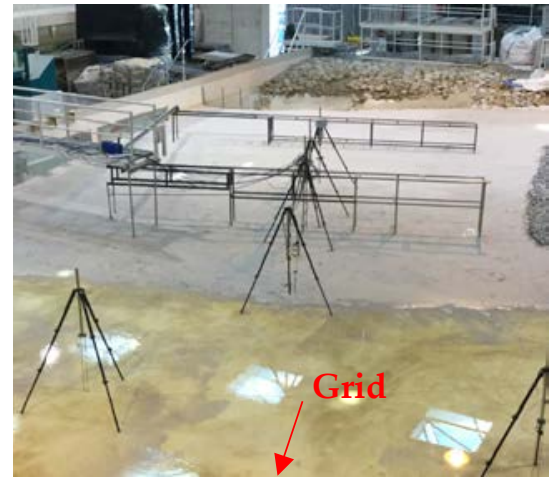

(a)

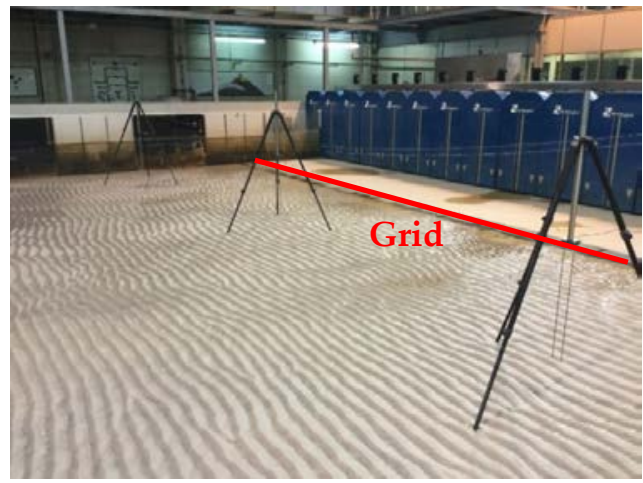

(b)

Figure 12. Offshore beach limits for scenario A: (a) Initial offshore profile limit (A.1); (b) Final offshore profile limit (A.1).

Recirculation of water inside the basin might be the cause for the presence of a longshore current toward the updrift limit of the tank, as observed at some instants. This might be due to the physical boundaries that reflect the downdrift currents that are generated in the surf zone. Note that the ADV is in depths where longshore currents should be weak, and thus the recirculation currents can change the flow direction.

Suspended sediment concentration peaks in scenario A.2, registered from $t=1890 \mathrm{~min}$ to $t=2010 \mathrm{~min}$ and from $t=2610 \mathrm{~min}$ to $t=2790 \mathrm{~min}$, are justified by the introduction of sediments through the nourishment, which also, consequently, led to a distancing of the dynamic equilibrium, or near-equilibrium, beach state. As referred to by [8], beach profiles far from the equilibrium present an increase in the beach dynamics. Just after the placement of the nourishment, there is a quick decrease of the sediment's volumes in the controlled cell, as shown in the topo-bathymetric variations (Figure 7) and the volumes' variation describing the durability of the nourishment (Figure 10). For scenario A.1, the total amounts of sediment that left the control volume that were fed at the updrift limit and collected in the downdrift limit were 2086, 1008, and $7632 \mathrm{~kg}$, respectively (in $26.5 \mathrm{~h}$ ), while the same values, respectively, for scenario A.2, were 3948, 958, and $7560 \mathrm{~kg}$ (in just $1200 \mathrm{~min}$ ). The net erosion rates estimated from the total amount of sediments that left the control volume, obtained by the bathymetric surveys, are $79 \mathrm{~kg} / \mathrm{h}$ for scenario A.1 and $197 \mathrm{~kg} / \mathrm{h}$ for scenario A.2. Scenario A.2 registered higher erosion rates leading to a greater loss of sediment volume from the control cell than for scenario A.1. However, the volume of sediments collected at downdrift was greater for scenario A.1. This behavior may indicate that there was a movement of the nourished sediment toward the upper part of the beach profile, or to deeper areas, which were not monitored. Nevertheless, looking at the net sediment transport, estimated from the monitored coastal cell volumes (Figure 10), the initial transport rate in scenario A.2 is superior to scenario A.1.

Apart from the morphodynamic response to the nourishment, the volumes in the control cell, the position of 0.3 contour, and the beach slope tend to equilibrium values that are analogous to the ones when there is no nourishment, as depicted in Figures 9-11. Due to the initially loose sand placed as nourishment, there was a fast decrease of the shoreface slope (Figure 11) during the first moments of scenario A.2, which indicates that the profile quickly re-adapted to the new morphological conditions $[8,30]$. With the sudden drop in the slope, the beach developed into an intermediate state showing a decreasing beach slope tendency, developing toward a dissipative state like the beach at the end of scenario A.1. The instant when the control cell volume reaches the previous volume before the nourishment would represent the timing required for a renourishment (nourishment lifetime concept [31]). Although the monitored coastal cell does not represent the entire beach and sediments leaving the monitored area cannot be completely tracked, it was assumed that the artificial nourishment had a lifespan of about $420 \mathrm{~min}(7 \mathrm{~h})$. 


\subsection{Laboratory Tests Constraints}

Over this work, there were several difficulties in the interpretation of the obtained laboratory results. These issues were mainly due to the low spatial resolution and small monitoring area of the bathymetric surveys, the low sand compaction, and the low representativity of the velocities and concentrations results, since only one point was monitored. The number of pieces of monitoring equipment available at the laboratory is of major concern. One of the main constraints during the laboratory tests was the lack of available instruments, limiting the characterization of the beach morphodynamics in terms of space and time resolution. Thus, it was not possible to fully comprehend and analyze the profile behavior and the hydrodynamic and sediment transport processes.

The end of scenario A.1 was defined by visual observations of the beach morphology. When the beach presented no significant shoreline retreat, it was assumed to be in a nearequilibrium or dynamic equilibrium state with the updrift incoming sediments. This is confirmed by the stability registered in the longshore and cross-shore velocities. However, the uncertainty of the equilibrium state, due to the lack of spatial resolution, may lead to important misinterpretations $[35,36]$. To guarantee the dynamic equilibrium state of the beach, one should define a quantitative criterion to determine that same state. One example is the work of [8] that registered that with a decrease in bed velocities the beach is most likely tending to a steady state.

The performed nourishment had a direct feeder effect, since there was an onshore sediment movement partially restoring the beach width. Sediments moving offshore might have fed the bar, producing a secondary effect, which results in further away wave energy dissipation through breaking and a consequent protection of the upper profile. However, due to the physical limitations of the profiler (in its length) and since, for scenario A.2, the emerged nourishment effect (increased beach width) disappeared rapidly, it is not possible to quantify the amount of sediment feeding the bar nor the upper shoreface.

Low spatial resolution ( 6 by $2 \mathrm{~m}$ monitored coastal cell) does not allow full comprehension of the existence of bathymetric gradients. Despite the apparent shoreline orientation, parallel to the wave generator, there is little information about the bathymetric contours that are responsible for the wave refraction and breaking, which influence the longshore sediments transport. The reflective effect of the basin walls might have led to some updrift sediment movement, which may explain the shoreline orientation despite the updrift sediments added by the funnels. The physical barriers of the wave basin might have influenced the spread rate of the nourishment, which can affect the retreat rates. By representing a physical barrier, it is most likely that recorded rates were smaller than for a scenario where no lateral barrier exists.

Initial conditions for both scenarios were affected by the lack of sand compaction, which led to initially higher sediment transport rates, making it difficult to correctly determine the time interval needed for both beaches' scenarios to reach a dynamic equilibrium or near-equilibrium state and for the nourishment effect to dissipate.

It was observed that the cross-shore and longshore sediment transport rates are much higher than predicted and intended for the laboratory tests. The nourishment dimensions and geometric configuration, combined with the re-circulation inside the wave basin, might have accelerated the morphological evolution of the modeled beach. Due to the high morphological changes to the beach over time, the relative position of the instruments to the shoreline changed greatly (the instruments measured different relative profile position and depths over time). The relative distance was influenced by the retreating shoreline and the advancing offshore limit of the profile.

\section{Conclusions}

Two sets of laboratory tests were conducted over a movable bed physical model, using an irregular wave climate. The first stage aimed to obtain a beach at a near dynamic equilibrium state, while the second stage introduced a nourishment containing $9080 \mathrm{~kg}$ of sand (induced perturbance) to alter the morphological, hydrodynamic, and sediment 
transport processes over the previously obtained equilibrium beach. Placing an artificial nourishment in the modeled beach led to an increase in the beach width and variations in its dynamics. A total value of $1.43 \mathrm{~m}^{3}$ of sediments left the monitored cell over the full duration of the test (scenarios A.1 and A.2). Although some areas of the cell experienced accretion, the volume balance is negative at all instants with exception of the instant when the artificial nourishment was introduced. The final beach for scenario A.2 evolved toward a similar volume and configuration to the beach at the end of scenario A.1. Although the size of the monitored coastal cell does not allow the observation of the accurate movement of the sediments, it was possible to determine the volume variation of the coastal cell and the nourishment efficiency: the lifetime of the artificial nourishment was about $420 \mathrm{~min}$.

In both scenarios, the cross-shore profiles have retreated, with scenario A.1 presenting a higher average retreat rate $(0.13 \mathrm{~cm} / \mathrm{min})$ than scenario A.2 $(0.11 \mathrm{~cm} / \mathrm{min})$. Despite the initial non-compacted sediments in the artificial nourishments, the nourishment reduced the shoreline retreat rate by about $15.4 \%$ when compared to the conditions presented in scenario A.1. The artificial nourishment presence also led to an increase in the hydrodynamic activity: the highest longshore and cross-shore velocity components and suspended sediment concentrations occurred during the first $540 \mathrm{~min}$ of scenario A.2. These results and the fast morphodynamic evolution of the nourishment and beach go according to [8] and [30], noting that when introducing a perturbation on the beach, such as an artificial nourishment, there is an increase in the beach dynamics.

The suspended sediment transport values computed from the collocated ADV and OBS are much lower than the total sediment transport estimated from volume balance, which suggests that the bed load is the dominant mode of transport. However, it is difficult to characterize sediment transport with only one point monitoring velocities and suspended sediment concentrations over the full beach extension, whose relative position in the surf zone changes due to cross-shore profile evolution (when located closer to the surfzone, the equipment would register higher velocities and suspended sediment concentrations). Due to the spatial variation of the sediment transport characteristics (e.g., cross-shore distribution of the longshore transport), more points all over the beach, with an ADV coupled with an OBS, should be monitored to correctly characterize sediment transport. Moreover, additional monitoring points would decrease the difficulties in adequately locating the measuring instruments due to the bed evolution and morphological evolution along the tests. To mitigate these issues, a similar system to the one described by [37] could be adopted.

To avoid some problems during laboratory tests with sand movable bed physical models, it is suggested that after the construction of the initial beach profile, before experiments start, the wave generators should run over a certain amount of time. This should be done to assess if the initial profile geometry is close to the equilibrium and to compact the sand to avoid its liquefaction. During this interval, it should be assessed if the profile/bathymetry is having an impact on the wave height (e.g., through reflection) and corrected if necessary. The instruments' location should be defined with precision after the sand is compacted, despite the difficulties in placing a support for a similar profiler measuring device.

The difficulties in predicting and anticipating the morphological evolution of the modeled beach create constraints in correctly locating the measuring equipment and obtaining accurate data. Future definition of laboratory procedures should account for the hereby described conditions to improve the model's accuracy and performance.

Author Contributions: Conceptualization, A.G. and C.C.; methodology, A.G.; software, A.G.; validation, A.G., C.C., F.V.-G., and P.A.S.; formal analysis, A.G.; investigation, A.G.; resources, C.C., F.V.-G., and P.A.S.; data curation, A.G. and C.C.; writing-original draft preparation, A.G.; writing-review and editing, C.C., F.V.-G., and P.A.S.; visualization, A.G.; supervision, C.C., F.V.-G., and P.A.S.; project administration, A.G. and C.C.; funding acquisition, A.G. and C.C. All authors have read and agreed to the published version of the manuscript.

Funding: This research received no external funding. 
Institutional Review Board Statement: Not applicable.

Informed Consent Statement: Not applicable.

Data Availability Statement: Not applicable.

Acknowledgments: A.G. is supported by the Foundation for Science and Technology PhD Grant SFRH/BD/103694/2014. Thanks to the Portuguese Foundation for Science and Technology (FCT) through the financial support to CESAM (national UID/AMB/ 50017/2013 and FEDER funds, within the PT2020 Partnership Agreement and Compete 2020). This work was financially supported by the project "Sandtrack-Beach nourishment: An integrated methodology for coastal management support", POCI-01-0145-FEDER-031779, funded by FEDER, through COMPETE2020-POCI, and by national funds (OE), through FCT/MCTES.

Conflicts of Interest: The authors declare no conflict of interest.

\section{References}

1. Capobianco, M.; Hanson, H.; Larson, M.; Steetzel, H.; Stive, M.J.F.; Chatelus, Y.; Karambas, T. Nourishment design and evaluation: Applicability of model concepts. Coast. Eng. 2002, 47, 113-135. [CrossRef]

2. Hanson, H.; Brampton, A.; Capobianco, M.; Dette, H.H.; Hamm, L.; Laustrup, C.; Spanhoff, R. Beach nourishment projects, practices, and objectives-A European overview. Coast. Eng. 2002, 47, 81-111. [CrossRef]

3. Bottin, R.R.; Earickson, J.A. Buhne Point, Humboldt Bay, California, Design for the Prevention of Shoreline Erosion, Hydraulic and Numerical Model Investigation. In Technical Report CERC84-5; Coastal Engineering Research Center, U.S. Army Engineer Waterways Experiment Station: Vicksburg, MS, USA, 1984; p. 340.

4. Grasso, F.; Michallet, H.; Barthélemy, E.; Certain, R. Physical modelling of intermediate cross-shore beach morphology: Transients and equilibrium states. J. Geophys. Res. 2009, 114, 15.

5. Grasso, F.; Michallet, H.; Barthélemy, E. Experimental simulation of shoreface nourishments under storm events: A morphological, hydrodynamic, and sediment grain size analysis. Coast. Eng. 2011, 58, 184-193. [CrossRef]

6. Dette, H.H.; Larson MMurphy, J.; Newe, J.; Peters, K.; Reniers, A.; Steetzel, H. Application of prototype flume tests for beach nourishment assessment. Coast. Eng. 2002, 47, 137-177. [CrossRef]

7. Grasso, F.; Michallet, H.; Barthélemy, E. Sediment transport associated with morphological beach changes forced by irregular asymmetric, skewed waves. J. Geophys. Res. 2011, 116, 12. [CrossRef]

8. Michallet, H.; Castelle, B.; Barthélemy, E.; Berni, C.; Bonneton, P. Physical modeling of three-dimensional intermediate beach morphodynamics. J. Geophys. Res. Earth Surf. 2013, 118, 1045-1059. [CrossRef]

9. Headland, J.; Smith, W.G.; Kotulak, P.; Alfageme, S. Coastal Protection Methods. In Handbook of Coastal Engineering; J. B. Herbich \& McGraw-Hill: London, UK, 1999; pp. 1-66.

10. Tondello, M.; Ruol, P.; Sclavo, M.; Capobianco, M. Model tests for evaluating beach nourishment performance. In Proceedings of the 26th International Conference on Coastal Engineering, Copenhagen, Denmark, 22-24 June 1998.

11. Van Duin, M.; Wiersma, N.; Walstra, D.; Van Rijnand, L.; Stive, M. Nourishing the shoreface: Observations and hindcasting of the Egmond case, The Netherlands. Coast. Eng. 2004, 51, 813-837. [CrossRef]

12. Grunnet, N.; Ruessink, B.; Walstra, D. The influence of tides, wind and waves on the redistribution of nourished sediment at Terschelling, The Netherlands. Coast. Eng. 2005, 52, 617-631. [CrossRef]

13. USACE. V-4 Beach Fill Design; USACE: Vicksburg, MS, USA, 2008; Volume 1100, p. 113.

14. van Heuvel, T. Sand Nourishment: A Flexible and Resilient, Adaptive Coastal Defence Measure; Climate of Coastal Cooperation: Amsterdam, The Netherlands, 2011; 7p.

15. González, M.; Medina, R.; Losada, M. On the design of beach nourishment projects using static equilibrium concepts: Application to the Spanish coast. Coast. Eng. 2010, 57, 227-240. [CrossRef]

16. Verhagen, H.J. Method for Artificial Beach Nourishment. In Proceedings of the 23rd Coastal Engineering Proceedings, Venice, Italy, 4-9 October 1992.

17. Hughes, S.A. Physical Models and Laboratory Techniques in Coastal Engineering; World Scientific: Singapore, 1993; 570p.

18. Bayram, A.; Larson, M.; Miller, H.C.; Kraus, N.C. Cross-shore Distribution of Longshore Sediment Transport: Comparison between Predictive Formulas and Field Measurements. Coast. Eng. 2001, 44, 79-99. [CrossRef]

19. Wang, P.; Ebersole, B.A.; Smith, E.R. Longshore Sand-Initial Results from Large-Scale Sediment Transport Facility, No. ERDC/CHLCHETN-II-46; Engineering and Development Center: Vicksburg, MS, USA, 2002; 12p.

20. Silva, R. Avaliação Experimental e Numérica de Parâmetros Associados a Modelos de Evolução Da linha de Costa. Ph.D. Thesis, Civil Engineering Department, University of Porto, Porto, Portugal, 2010.

21. Guimarães, A.; Lima, M.; Coelho, C.; Silva, R.; Veloso-Gomes, F. Groin impacts on updrift morphology: Physical and numerical study. Coast. Eng. 2016, 109, 63-75. [CrossRef]

22. Vera-Cruz, D. Artificial Nourishment of Copacabana Beach. In Proceedings of the 13th Intl. Conference on Coastal Engineering, Vancouver, BC, Canada, 10-14 October 1972. 
23. Johnson, B.D.; Smith, E.R. Material placement in the nearshore: Laboratory and numerical model investigation. In Proceedings of the 33rd Conference on Coastal Engineering, Santander, Spain, 1-6 July 2012.

24. Smith, E.R.; Mohr, M.C.; Chader, S.A. Laboratory experiments on beach change due to nearshore mound placement. Coast. Eng. 2017, 121, 119-128. [CrossRef]

25. Dean, R.G. Equilibirum Beach Profiles: Characteristics and Applications. J. Coast. Res. 1991, 7, 53-84.

26. Roberts, T.M.; Wang, P.; Kraus, N.C. Limits of beach and dune erosion in Response to Wave Runup Elucidated from SUPERTANK; Coastal Sediments '07; ASCE: Reston, VA, USA, 2007.

27. Sontek. Sontek ADVField Acoustic Doppler Velocimeter-Tecnhical Documentation; Sontek: San Diego, CA, USA, 2001.

28. Cea, L.; Puertas, J.; Pena, L. Velocity measurements on highly turbulent free surface flow using ADV. Exp. Fluids 2007, 42, 333-348. [CrossRef]

29. Carrilho, A. Morfodinâmica e Transporte Sedimentar Longitudinal na Praia de Mira. Master's Thesis, Civil Engineering Department, University of Aveiro, Aveiro, Portugal, 2013.

30. Marino-Tapia, I.; Russell, P.; O'Hare, T.; Davidson, M.; Huntley, D. Cross-shore sediment transport on natural beaches and its relation to sandbar migration patterns: 1 . Field observations and derivation of a transport parameterization. J. Geophysical. Res. 2007, 112, C03001. [CrossRef]

31. Klein, A.H.F.; Miot da Silva, G.; Ferreira, Ó.; Dias, J.A. Beach sediment distribution for a headland bay coast. J. Coast. Res. 2004, SI, 285-293.

32. Bosboom, J.; Stive, M. Coastal Dynamics I; Lecture Notes CIE4305 Division of Hydraulic and Geotechnical Engineering Delft; Hydraulic Engineering Section, Delft Academic Press: Delft, The Netherlands, 2015.

33. Wang, P.; Ebersole, B.A.; Smith, E.R. Beach-Profile Evolution under Spilling and Plunging Breakers. J. Waterw. Port Coast. Ocean Eng. 2003, 129, 41-46. [CrossRef]

34. Aagaard, T.; Greenwodd, B.; Hughes, M. Sediment transport on dissipative, intermediate and reflective beaches. Earth-Sci. Rev. 2013, 124, 32-50. [CrossRef]

35. Crosato, A.; Desta, F.B.; Cornelisse, J.; Schuurman, F.; Uijttewaal, W.S. Experimental and numerical findings on the long-term evolution of migrating alternate bars in alluvial channels. Water Resour. Res. 2012, 48, 14. [CrossRef]

36. Crosato, A. Issues in Laboratory Experiments of River Morphodynamics; RCEM: Padova, Italy, 2017.

37. Molfetta, M.G.; Bruno, M.F.; Pratola, L.; Rinaldi, A.; Morea, A.; Preziosa, G.; Pasquali, D.; Di Risio, M.; Mossa, M. A Sterescopic System to Measure Water Waves in Laboratories. Remote Sens. 2020, 12, 2288. [CrossRef] 